\title{
Relationship Between the Volatility of Stock Returns and the Volatility of Macroeconomic Variables: A Case of Turkey
}

\author{
Tuğba Dayıŏglu, , *, Yılmaz Aydın² \\ ${ }^{1}$ Department of Economics and Finance, Nisantası Unıversity, Istanbul, Turkey \\ ${ }^{2}$ Department of Economics, Nisantası Unıversity, Istanbul, Turkey
}

Email address:

tugba.dayioglu $@$ nisantasi.edu.tr (T. Dayıglu), yilmaz.aydın $a$ nisantasi.edu.tr (Y. Aydın)

${ }^{*}$ Corresponding author

\section{To cite this article:}

Tuğba Dayığlu, Yılmaz Aydın. Relationship Between the Volatility of Stock Returns and the Volatility of Macroeconomic Variables: A Case of Turkey. American Journal of Theoretical and Applied Business. Vol. 5, No. 2, 2019, pp. 40-46. doi: 10.11648/j.ajtab.20190502.13

Received: July 5, 2019; Accepted: August 9, 2019; Published: September 24, 2019

\begin{abstract}
In this paper, we examined the relationship between BIST-100 Index (SPI) and a set of macroeconomic variables volatility using Vector Autoregressive (VAR) model. The relationship between the stock market and macroeconomic variables has been subjected to serious economic research. A stock market plays important role for the reallocation of funds in many sectors of an economy. The macroeconomic factors make investors to choose the stock because investors are interested to know about the factors affecting the working of stock to manage their portfolios. Some investors show the stock prices volatility is based on directional trend in the stock prices but actually volatility is amount of fluctuation in stock prices. For this purpose we used the volatility of the variables. This study period 2006-2018 stock market using monthly data for Turkey is to examine the relationship between stock return volatility and macroeconomic volatility. We used the macroeconomic variables volatility these are industrial production (IP), money supply (M1), inflation rate (CPI), US dollar equivalent exchange rate (EX) and oil prices (OIL). We used montly data for the period between january 2006 and december 2018. Asymmetric GARCH models are used for the series volatility. The best performing GARCH model in these models are considered as volatlity. Exchange rate and industrial production index have an important effect on stock market volatility.
\end{abstract}

Keywords: Stock Markets Volatility, Asymmetric GARCH Models, VAR Model

\section{Introduction}

The periods of high stock market volatility in advanced and emerging markets have intensified discussions about the reasons for such price movements. Accordingly, experiments were conducted to examine the relationship between stock market volatility and macroeconomic variables. The theoretical motivation of such a link is inspired by the in simple discounted current-value model of the stock price. In this model, the conditional variance of the stock price is based on the conditional variance of the expected future cash flows and discount rates, and the conditional covariances between them.

The total value of the company's share depends on the state of the economy, and a change in the uncertainty level regarding future macroeconomic conditions will lead to a proportional change in the volatility of stock returns.
There are only a few studies investigating the impact of macroeconomic volatility on volatile equity market volatility. The study [16] has shown that macroeconomic variables, more clearly inflation, industrial production and money supply - will determine the stock market volatility for the US. Schwert's finding provides weak evidence that macroeconomic volatility determines stock market volatility. A study based on data from Finland $[10,11]$ shows that one-third and more than two-thirds of the changes in conditional stock market volatility are conditional on macroeconomic volatility; ie, inflation, industrial production and money supply. The study [12] examined the relationship between conditional stock market volatility and conditional macroeconomic volatility with UK data. Morelli's finding shows that macroeconomic volatility does not explain the equity market volatility [13]. Recently, the study [3] expanded the work of the study [14] using data from thirteen stock markets. 
The purpose of this article is to examine whether the change in the volatility of Borsa Istanbul (BIST) index over time can be explained by the volatility of the macroeconomic variables, or to investigate the impact of this relationship on the stock index volatility in the mentioned years.

If the volatility of the stock market is a measure of the risk or uncertainty of the stock market, knowing how the volatility in macroeconomic variables affects the stock market volatility will help us better understand the impact of the determinants and changes in stock risk.

Furthermore, policy makers will be able to take appropriate policy measures to reduce the risk that macroeconomic volatility will have on stock market volatility.

The sections of the article are the first part of the introduction and the second part defines the data set. In the third chapter, conditional volatility models and prediction for series stability and volatility are presented. The relations between conditional stock market volatility and conditional macroeconomic volatility are analyzed in the fourth section by VAR model. In the fifth and last section, the final part of the article is included.

\section{Data and Methodology}

Data set the stock price of the BIST-100 index, which is the Turkish stock price indicator (SPI), is used for the January-December 2018 period and the return series is used. Price quotations are the closing prices of the last trading day of each month. The macroeconomic variables used monthly data are taken from the Central Bank of the Republic of Turkey. BIST-100 Index is a dependent variable and the others are independent variables. The macroeconomic independant variables are industrial production index (IP), money supply (M1), consumer price index (CPI), exchange rate $(\mathrm{EX})$ and oil prices index (OP).

Macroeconomic time series includes unit root analysis because of the stability of the series. In this study the stationary has been tested with Dickey Fuller and PhillipsPerron (PP) tests. Variables are used as return series by taking logarithmic differences. The empirical methods employed in this paper are standard tools obtained from Vector Autoregressive (VAR) model. Firstly, we examined variables whether they have seasonal movements and unit root or not.

After find the all series stationary we estimated the stock market index volatility and another macroe-conomic fundemantals factor variables volatility with asymmetric
GARCH models that using the best fit Asymmetric GARCH model. Taking the best model is used for the volatility of each series. We determined the all the variables volatility for using in the VAR model to find the relation way to eachother.

Before starting the study we examined variables in terms of their unit root. In this process, we tried to identify whether series have stationary using unitroot tests for each variables. For prepering the VAR model we identified seection of lags using Akaike and Schwarz, Final prediction error (AIC, SCW, FPE).

\section{Empirical Results}

The GARCH model was introduced by the study [1] as a generalized version of the study [6] Autoregressive Conditional Heteroscedasticity (ARCH). The GARCH(p,q) model suggests that conditional variance of returns is a linear function of lagged conditional variance terms and past squared error terms. The standard $\operatorname{GARCH}(\mathrm{p}, \mathrm{q})$ model specification is as follows:

$$
\sigma_{t}^{2}=\varpi+\sum_{i=1}^{p} \alpha_{i} \varepsilon_{t-i}^{2}+\sum_{j=1}^{q} \beta_{j} \sigma_{t-j}^{2}
$$

The mean equation provided in (3.1) is written as a function of exogenous variables with an error term. In this equation, $\omega$ is a constant term, $\alpha_{1} \varepsilon_{i}^{2}$ is an ARCH term and $\beta_{j} \sigma_{t^{2}-\mathrm{j}}$ is the GARCH term. This model is widely used, especially in financial time series analysis. While the vast majority of the earlier studies relied on the ARCH framework, there is now a large and diverse time series literature on volatility modelling (for instance, Asymmetric GARCH modelling, such as EGARCH, GJR-GARCH, APARCH, ACGARCH).

Table 1 shows Exponancial GARCH (EGARCH) model proposed by (Such as: [15])is the earliest extension of the GARCH model that incorporates asymmetric effects in returns from speculative prices. The GJR-GARCH $(p, q)$ model is another volatility model that allows asymmetric effects. This model was proposed by the [7]. In a recent article that introduced a class of autoregressive conditional heteroscedastic models called Asymmetric Power Autoregressive Conditional Heteroscedastic (APARCH) models. They proposed the component GARCH model in order to investigate the long-run and the short-run movement of volatility [4]. The component GARCH or CGARCH model allows mean reversion to a time.

Table 1. Conditional Heteroscedasticity Models.

\begin{tabular}{ll}
\hline Equation & Model \\
\hline$\sigma_{t}^{2}=\omega+\sum_{i=1}^{p} \alpha_{i} \varepsilon_{t-i}^{2}$ & $\operatorname{ARCH}(1)$ \\
$\sigma_{t}^{2}=\varpi+\sum_{i=1}^{p} \alpha_{i} \varepsilon_{t-i}^{2}+\sum_{j=1}^{q} \beta_{j} \sigma_{t-j}^{2}$ & $\operatorname{GARCH}(1,1)$ \\
$\log \left(\sigma_{t}^{2}\right)=\varpi+\sum_{i=1}^{p} \alpha_{i}\left|\frac{s_{t-i}}{\sigma_{t-i}}\right|+\sum_{j=1}^{q} \beta_{j} \log \left(\sigma_{t-j}^{2}\right)+\sum_{k=1}^{r} \gamma_{k} \frac{s_{t-k}}{\sigma_{t-k}}$ & $\operatorname{EGARCH}(1,1)$ \\
$\sigma_{t}^{2}=\varpi+\sum_{i=1}^{p}\left(\alpha_{i} \varepsilon_{t-i}^{2}+\gamma S_{t-i}^{-} \varepsilon_{t-i}^{2}\right)+\sum_{j=1}^{q} \beta_{j} \sigma_{t-j}^{2}$ & $\operatorname{GJR}-\operatorname{GARCH}(1,1)$ \\
$\sigma_{t}^{2}=\varpi+\sum_{i=1}^{p} \alpha_{i}\left(\left|\varepsilon_{t-i}\right|-\gamma_{i} \varepsilon_{t-i}\right)^{\delta}+\sum_{j=1}^{q} \beta_{j} \sigma_{t-j}^{\delta}$ & APARCH(1,1) \\
\hline
\end{tabular}

a) $\alpha$ external shocks, $\gamma$ leverage effect and $\beta$ continuity (b) When Dummy variable $\mathrm{St}_{\mathbf{l}} \boldsymbol{\varepsilon}_{\mathbf{t}-\mathbf{1}}<0$ it is thedummy variable that replaces 0 . This term allows for the asymmetry effect (c) $\gamma$ represents the leverage or asymmetry parameter, and $\delta$ represents the force parameter. 
In this study we took all the series as a return series. We also calculate the descriptive statistics for the exchange rate returns of each countries and summarize them in Table 2 . In
Table 2, skewness, kurtosis, Jarque-Bera normality test, Q and Q2Ljung-Box test statistics and ARCH-LM test results are presented for all series.

Table 2. Descriptive Statistics.

\begin{tabular}{|c|c|c|c|c|c|c|c|}
\hline Returs & Mean & Skewness & Kurtosis & J. B. & $Q(12)$ & $Q(12) ’ 2$ & $\operatorname{ARCH}(2)$ \\
\hline rSPI & 1.594367 & 1.569982 & 36.84319 & $\begin{array}{l}4679.806 \\
(0.0000)\end{array}$ & $\begin{array}{l}42.144 \\
(0.0015)\end{array}$ & $\begin{array}{l}113.44 \\
(0.5688)\end{array}$ & $\begin{array}{l}13.5972 \\
(0.0001)\end{array}$ \\
\hline rIP & 3.645578 & 3.163712 & 51.56887 & $\begin{array}{l}13504.01 \\
(0.0000)\end{array}$ & $\begin{array}{l}45.675 \\
(0.0023)\end{array}$ & $\begin{array}{l}17.2237 \\
(0.6744)\end{array}$ & $\begin{array}{l}11.0000 \\
(0.0000)\end{array}$ \\
\hline rM1 & 6.440845 & 12.35674 & 91.6233 & $\begin{array}{l}17045.5 \\
(0.0000)\end{array}$ & $\begin{array}{l}0.05456 \\
(0.7753)\end{array}$ & $\begin{array}{l}0.3277 \\
(0.4577)\end{array}$ & $\begin{array}{l}14.31084 \\
(0.0003)\end{array}$ \\
\hline rCPI & 4.211765 & 2.883569 & 37.10956 & $\begin{array}{l}4567.538 \\
(0.0000)\end{array}$ & $\begin{array}{l}67.4590 \\
(0.2322)\end{array}$ & $\begin{array}{l}56.3345 \\
(0.3487)\end{array}$ & $\begin{array}{l}12.3422 \\
(0.0002)\end{array}$ \\
\hline rOIL & 1.592478 & 0.856993 & 46.84334 & $\begin{array}{l}6789.806 \\
(0.0000)\end{array}$ & $\begin{array}{l}0.58945 \\
(0.0056)\end{array}$ & $\begin{array}{l}0.05359 \\
(0.4578)\end{array}$ & $\begin{array}{l}8.2377 \\
(0.0000)\end{array}$ \\
\hline rMEX & 1.687356 & 3.127745 & 51.56997 & $\begin{array}{l}3456.01 \\
(0.0000)\end{array}$ & $\begin{array}{l}0.4328 \\
(0.0012)\end{array}$ & $\begin{array}{l}(0.0679) \\
(0.7122)\end{array}$ & $\begin{array}{l}5.1289 \\
(0.0000)\end{array}$ \\
\hline
\end{tabular}

The kurtosis coefficients were found to be greater than 3 , implying a fat-tailed empirical distrubution of there turns overall the periods. The JB normality test, based on skewness and kurtosis coefficient rejects the null hypothesis of normal distribution for all countries any reasonable level. If we consider the sample, given the fact that there return series exhibited some excess kurtosis, it can be predicted that a fatter-tailed distrubutions, such as the Student or may be a GED, should generate better results than simply a normal distrubution. The result of $\mathrm{Q}$ statistics show that the null hypothesis of no serial correlation cannot be rejected for return series [2].

In this study we calculated the volatility with asymmetric GARCH model and we used model selection criteria all the best fit GARCH model. Find the all series stationary we estimated the all variables volatility with asymmetric GARCH models that using the best fit Asymmetric GARCH model. Taking the best model is used for the volatility of each series. Finally we used for volatility the best fit GARCH model for all the variables. The variables volatility with best fit Asymmetric GARCH model is taken in Table 3.

Table 3. Volatility of Variables.

\begin{tabular}{|c|c|c|c|c|c|}
\hline $\begin{array}{l}\text { rISE } \\
\text { EGARCH(1,0)- }\end{array}$ & $\begin{array}{l}\text { rIP } \\
\operatorname{APARCH}(1,0)\end{array}$ & $\begin{array}{l}\text { rM1 } \\
\operatorname{ACGARCH}(1,0)\end{array}$ & $\begin{array}{l}\text { rCPI } \\
\text { GJR-GARCH(1,0) }\end{array}$ & $\begin{array}{l}\text { rOIL } \\
\text { GJR-GARCH(1,0) }\end{array}$ & $\begin{array}{l}\text { rEXC EGARCH- } \\
(1,1)\end{array}$ \\
\hline Distribution & GED & GED & GED & Student-t & GED \\
\hline Constant (M) & $\begin{array}{l}-1.5720 \\
{[0.4262]} \\
(0.0002)\end{array}$ & $\begin{array}{l}0.5634 \\
{[0.0068]} \\
(0.0000)\end{array}$ & $\begin{array}{l}-1.8157 \\
{[0.4813]} \\
(0.0002)\end{array}$ & - & $\begin{array}{l}0.5209 \\
{[0.0061]} \\
(0.0000)\end{array}$ \\
\hline $\operatorname{AR}(1)$ & $\begin{array}{l}-0.2002 \\
{[0.0581]} \\
(0.0006)\end{array}$ & $\begin{array}{l}-0.2358 \\
{[0.02210]} \\
(0.0000)\end{array}$ & $\begin{array}{l}-0.2669 \\
{[0.1117]} \\
(0.0169)\end{array}$ & $\begin{array}{l}-0.6777 \\
{[0.0630]} \\
(0.0000)\end{array}$ & $\begin{array}{l}-0.0069 \\
{[0.0012]} \\
(0.0005) \\
10.9213\end{array}$ \\
\hline $\mathrm{MA}(1)$ & - & - & - & - & (0.0000) \\
\hline Constant(V) & - & - & - & $\begin{array}{l}7.0880 \\
{[2.7043]} \\
(0.0088)\end{array}$ & $\begin{array}{l}10.9213 \\
{[1.5793]} \\
(0.0000)\end{array}$ \\
\hline $\operatorname{ARCH}(\alpha)$ & - & - & $\begin{array}{l}2.9501 \\
{[1.1620]} \\
(0.0111)\end{array}$ & $\begin{array}{l}0.01873 \\
{[0.0055]} \\
(0.0004)\end{array}$ & - \\
\hline $\operatorname{GARCH}(\beta)$ & - & - & $\begin{array}{l}0.1289 \\
{[0.0460]} \\
(0.0051)\end{array}$ & $\begin{array}{l}0.1951 \\
{[0.07527]} \\
0.0095\end{array}$ & - \\
\hline $\operatorname{EGARCH}(\alpha)$ & - & - & - & - & $\begin{array}{l}{[0.1199]} \\
(0.0006)\end{array}$ \\
\hline EGARCH $(\beta)$ & - & - & - & - & $\begin{array}{l}0.0184 \\
{[0.0057]} \\
(0.0000)\end{array}$ \\
\hline $\operatorname{EGARCH}(\gamma)$ & - & - & - & - & $\begin{array}{l}-1.5243 \\
{[0.2445]} \\
(0.0000)\end{array}$ \\
\hline GJRGARCH $(\gamma)$ & - & - & $\begin{array}{l}2.2487 \\
{[0.7138]} \\
(0.0001)\end{array}$ & - & - \\
\hline
\end{tabular}




\begin{tabular}{|c|c|c|c|c|c|}
\hline $\begin{array}{l}\text { rISE } \\
\text { EGARCH(1,0)- }\end{array}$ & $\begin{array}{l}\text { rIP } \\
\operatorname{APARCH}(1,0)\end{array}$ & $\begin{array}{l}\text { rM1 } \\
\operatorname{ACGARCH}(1,0)\end{array}$ & $\begin{array}{l}\text { rCPI } \\
\text { GJR-GARCH(1,0) }\end{array}$ & $\begin{array}{l}\text { rOIL } \\
\text { GJR-GARCH(1,0) }\end{array}$ & $\begin{array}{l}\text { rEXC EGARCH- } \\
(1,1)\end{array}$ \\
\hline Distribution & GED & GED & GED & Student-t & GED \\
\hline A-CGARCH $(\gamma)$ & - & $\begin{array}{l}0.3297 \\
{[0.1023]} \\
(0.0001)\end{array}$ & - & - & - \\
\hline $\operatorname{APARCH}(\alpha)$ & $\begin{array}{l}0.6994 \\
{[0.2458]} \\
(0.0044)\end{array}$ & - & - & - & \\
\hline $\operatorname{APARCH}(\beta)$ & $\begin{array}{l}0.3734 \\
{[0.1144]} \\
(0.0011)\end{array}$ & - & - & & \\
\hline $\operatorname{APARCH}(\gamma)$ & $\begin{array}{l}0.4226 \\
{[0.1261]} \\
(0.0008) \\
0.6171\end{array}$ & - & - & - & - \\
\hline $\operatorname{APARCH}(\delta)$ & $\begin{array}{l}{[0.1916]} \\
(0.0007)\end{array}$ & - & - & - & - \\
\hline t-distribution & $\begin{array}{l}- \\
0.3711\end{array}$ & $-\overline{0.4189}$ & - & & 0.2889 \\
\hline GED param. & $\begin{array}{l}{[0.0630]} \\
(0.0000)\end{array}$ & $\begin{array}{l}{[0.0489]} \\
(0.0000)\end{array}$ & - & & $\begin{array}{l}{[0.0346]} \\
(0.0000)\end{array}$ \\
\hline AIC & 7.0365 & 11.4225 & 7.0745 & 12.8818 & 13.6829 \\
\hline $\mathrm{SC}$ & 7.1864 & 11.6152 & 11.6152 & 12.8903 & 13.8429 \\
\hline LL & 477.4848 & 864.4813 & 864.4813 & 849.5671 & 720.1436 \\
\hline $\mathrm{Q}(12)$ & $\begin{array}{l}13.030 \\
(0.3679)\end{array}$ & $\begin{array}{l}34.768 \\
(0.0321)\end{array}$ & $\begin{array}{l}34.768 \\
(0.0321)\end{array}$ & $\begin{array}{l}26.745 \\
(0.0080)\end{array}$ & 27.669 \\
\hline Q2(12) & $\begin{array}{l}5.3369 \\
(0.9467)\end{array}$ & $\begin{array}{l}9.8962 \\
(0.6259)\end{array}$ & $\begin{array}{l}9.8962 \\
(0.6259)\end{array}$ & $\begin{array}{l}17.220 \\
(0.3611)\end{array}$ & $\begin{array}{l}17.442 \\
(0.1347)\end{array}$ \\
\hline $\mathrm{LM}(2)$ & $\begin{array}{l}2.7713 \\
(0.2543)\end{array}$ & $\begin{array}{l}0.1045 \\
(0.9008)\end{array}$ & $\begin{array}{l}0.1045 \\
(0.9008)\end{array}$ & & \\
\hline$\delta=1$ & $\begin{array}{l}0.5634 \\
(0.0000)\end{array}$ & & - & & \\
\hline$\delta=2$ & $\begin{array}{l}1.3828 \\
(0.4239)\end{array}$ & & - & & \\
\hline
\end{tabular}

i. Figures in parenthesis represent the $p$ values, while the figures in brackets represent standard deviation i. LM, TR2 denotes the test statistics for ARCH (c) ii.*indicates statistical significance at the 5\% level. iii. Q, Q2 denotes the Ljung-Box Test statistics for residual serial correlation iv. LM, TR2 denotes the test statistics for $\operatorname{ARCH}(\mathrm{c}) \mathrm{v}$. ARMA(p,q) for the mean models and determined $\operatorname{ARMA}(1,0)$ vi. $\mathrm{M}$ is the equation for the mean, while $\mathrm{V}$ is the equation for variance

The models were estimated by assuming normal, Student- $t$ and GED distributions. We used as ymmetric GARCH models and choosed the best volatility models using log likelihood (LL), AIC, Shwartz Information Criteria (SIC). The best model must have the lowest AIC, SIC orhighest LL value.

Table 3 shows the all the series volatility that estimated from the Asymmetric GARCH models. We estimated v. olatility with asymmetric GARCH models because all the variables show the fat tailed and asymmetric structure so we should not use the symmetric GARCH models if our data is not suitable. So we calculated all the volatility with asymmetric GARCH models. We compared all the models to find the best fit asymmetric GARCH model with model selection criteria MAE (Mean Absolute Error), MAPE (Mean Absolute Percent Error) and TIC (Theil Inequality Criteria), are used.

After finding the best volatility for each variables we used as a variable for using in the VAR model. We used all the variables logaritmic form to find the return series also we used the stationary form for finding the volatility. The return series are determined taking the logarithmic form so taking the first differences series will be statioary as usual.
After finding the volatlity variables we designed the all variables stationary results with $\mathrm{ADF}$ and $\mathrm{PP}$ test are discussed in the Table 4. Even these series are prepered for VAR model. The all series stationary results are showed in Table 3.

Table 4. Results of Augmented Dickey Fuller Test And Philipps Peron Test of the Return Series.

\begin{tabular}{lll}
\hline Variables & $\begin{array}{l}\text { Augmented Dickey Fuller } \\
\text { (ADF)Level Trend and Intercept }\end{array}$ & $\begin{array}{l}\text { Phillips Perron } \\
\text { (PP) }\end{array}$ \\
\hline rISE & $-6.2334^{*}$ & $-8.67332^{*}$ \\
rIP & $-6.3318^{*}$ & $-9.50412^{*}$ \\
rM1 & $-8.6633^{*}$ & $-9.64299^{*}$ \\
rEXC & $-7.8812^{*}$ & $-7.84511^{*}$ \\
rOIL & $-9.3341^{*}$ & $-9.02522^{*}$ \\
rCPI & $-7.3355^{*}$ & $-11.3421^{*}$ \\
\hline
\end{tabular}

*\%5 probability that statistically significant that MacKinnon (1991) Augmented Dickey-Fuller critical value

-3.9181 . \% 5 statistically significant. Phillips-Perron test critical value -4.462 'dir

Table 4 shows that all of test statistics has a first difference level and \% 5 significant degree in MacKinnon $p$ values. ADF statistics and PP test show the macroeconomic 
variables are sationary process such as $\mathrm{ISE} \sim \mathrm{I}(0), \mathrm{IP} \sim \mathrm{I}(0)$, $\mathrm{M} 1 \sim \mathrm{I}(0), \mathrm{EXC} \sim \mathrm{I}(0), \mathrm{OIL} \sim \mathrm{I}(0), \mathrm{CPI} \sim \mathrm{I}(0)$. All the stationary variables are taken for the volatility and before we searched in what kind conditional heteroskedasticiy model we should use thus we searched in the variables

When we look at the Table 4 all the variables are taken level stationary I(0) with suitable lags. These fundementals variables will be used for the VAR model with stationay form. After stationary process we determined lag order of the VAR model is selected based on Akaike Information Criteria (AIC), Final Prediction Error (FPE), Schwarz Citeria (SC) exc. The order of VAR Model was shown in Table 5.

Table 5. VAR Model Lag Selection Criteria.

\begin{tabular}{lllll}
\hline lag & LR & FPE & AIC & SC \\
\hline 0 & 67.4577 & $2.41 \mathrm{e}+42$ & 95.4478 & 95.4478 \\
1 & 54.3456 & $2.43 \mathrm{e}+42$ & 98.6755 & 88.1799 \\
2 & 40.1123 & $2.65 \mathrm{e}+39$ & 86.2355 & 86.3499 \\
3 & $40.2234^{*}$ & $2.67 \mathrm{e}+39$ & 89.0127 & 89.3356 \\
4 & 42.1256 & $2.34 \mathrm{e}+39$ & 90.8823 & 91.2218 \\
5 & 27.0552 & $2.15 \mathrm{e}+39^{*}$ & $71.0722^{*}$ & $68.6756^{*}$ \\
6 & 40.2256 & $2.22 \mathrm{e}+39$ & 89.3313 & 90.5644 \\
\hline
\end{tabular}

*indicates lag order selected by the criterion

LR: sequential modified LR test statistic (each test at 5\% level)

FPE: Final prediction error

AIC: Akaike information criterion

SC: Schwarz Criterion

We defined the lag order as 5th lag order by AIC and SC. Determine the all variables in the VAR model system we should find the Variance the Decompositon for designing the sort of the variables endogenaity in the VAR model. Variance Decompositon results show one standart deviation shock for each variables explained by other vaiables.

After finding the all series stationary and finding the dependant variable as a volatility of stock market index we identified the selection of lag to VAR model using Akaike Information Criteria (AIC). The optimal lag is fifth order then we estimated VAR model. VAR model is one of the most successful, flexible and easy to use models for the analysis of multivariate time series. It is a natural extension of the univariate autoregressive model to dynamic multivariate time series. The VAR model has proven to be especially useful for describing the dynamic behavior of economic and financial time series.

In this study find the relationship between the stock market indeks volatility and another chosen macro economic variable we use two models first Aymmetric GARCH models for volatility and finding the relationship between the volatility and macroeconomic variables we used VAR model.

The model developed by the studies $[18,20]$ is based on the Granger causality test model and if there are two internal variables in the model, each is associated with the delayed values of both its own and other internal variables until a certain period. Sims, structural criticize the internalexternal distinction in the model. It also indicates that this distinction is artificial. If we take Yt and Xt series model is defined as follows [22].

$$
y_{t}=b_{10}-b_{12} x_{t}+\gamma_{11} y_{t-1}+\gamma_{12} x_{t-1}+\varepsilon_{y t}
$$

$$
x_{t}=b_{20}-b_{21} y_{t}+\gamma_{21} y_{t-1}+\gamma_{22} x_{t-1}+\varepsilon_{x t}
$$

The error terms (structural shocks) ${ }_{\mathrm{yt}}$ and $\mathrm{xt}_{\mathrm{xt}}$ are white noise innovations with standard deviations $\mathrm{y}_{\mathrm{y}}$ and $\mathrm{x}$ and a zero covariance. The lagged values of $\mathrm{Y}$ affect the $\mathrm{X}$ variable and the lagged values of $\mathrm{X}$ affect the $\mathrm{Y}$ variable. In this model, only the delayed variables are to be found on the right side of the equations with the least squares method values will be consistent.

After having the appropriate delay lengths in VAR system, effect-response functions are obtained. Impact-response functions the effects of the shocks on the variables and the effect of what is the effect of tables or graphical representation reveals with this process, it is understood which shocks occur in the shocks and how these variableswill react to these shocks.

The variance decomposition investigates the percentage of the change in a variable by itself and the other by the other variables. If the variance in the variance is almost $100 \%$, it is described as an external variable. In this analysis sorting of variables is very important. The sequence is done from the outside to the inside for VAR analysis [23].

What is the percentage of change in the variance of each of the variables examined and percentages by other variables. Variables are determined as internal or external. They can also be used as a side evaluation about what they do not $[19,20]$.

The relationship between stock market volatility and macroeconomic variables was estimated using the Vector Autoregressive Regression (VAR) model. VAR model is defined with variance decomposition. Table 6 shows the variables are exogeneous or indegenous with Variance Decompositon results.

\begin{tabular}{|c|c|c|c|c|c|c|}
\hline Term & rISE & RIP & RM1 & rEXC & rOIL & rCPI \\
\hline \multirow[t]{2}{*}{1} & 100.0000 & 0.000000 & 0.000000 & 0.000000 & 0.000000 & 0.000000 \\
\hline & $(0.0000)$ & $(0.0000)$ & $(0.0000)$ & $(0.0000)$ & $(0.0000)$ & $(0.00000)$ \\
\hline \multirow[t]{2}{*}{2} & 99.85708 & 0.053265 & 0.23557 & 0.454294 & 0.321802 & 0.321802 \\
\hline & $(2.09468)$ & $(0.63097)$ & $(0.61045)$ & $(1.52482)$ & (1.16771) & $(2.16771)$ \\
\hline \multirow[t]{2}{*}{3} & 97.55888 & 0.651469 & 0.223188 & 1.555744 & 0.680722 & 0.570722 \\
\hline & $(2.61310)$ & $(1.11260)$ & (1.25499) & (1.92350) & (1.25919) & (1.44919) \\
\hline \multirow[t]{2}{*}{4} & 96.37428 & 0.560114 & 0.371717 & 2.685175 & 0.998710 & 0.788710 \\
\hline & (2.59964) & (1.39879) & (1.53341) & $(2.16415)$ & (1.37444) & (1.23443) \\
\hline \multirow[t]{2}{*}{5} & 95.89057 & 0.229254 & 0.784366 & 3.553999 & 1.561815 & 0.1451815 \\
\hline & (3.38353) & $(2.09186)$ & $(1.73486)$ & (2.34298) & (1.39292) & (1.57322) \\
\hline \multirow[t]{2}{*}{6} & 95.31322 & 0.450755 & 0.676233 & 2.886885 & 0.898905 & 0.49825 \\
\hline & $(3.66312)$ & $(2.15262)$ & $(1.83081)$ & $(2.32861)$ & $(1.58960)$ & $(1.19460)$ \\
\hline \multirow[t]{2}{*}{7} & 95.56921 & 0.674561 & 0.678518 & 2.897314 & 1.145400 & 1.12500 \\
\hline & (3.88923) & $(2.23326)$ & (1.82007) & (2.37559) & (1.67998) & (1.49528) \\
\hline \multirow[t]{2}{*}{9} & 95.12693 & 0.145353 & 0.784254 & 2.431247 & 0.068219 & 0.012219 \\
\hline & (3.96465) & $(2.22442)$ & (1.80644) & $(2.38458)$ & (1.66340) & $(1.52240)$ \\
\hline \multirow[t]{2}{*}{9} & 94.12848 & 0.256553 & 0.167893 & 2.512913 & 1.734736 & 1.912736 \\
\hline & $(4.05534)$ & (2.25191) & (1.80433) & $(2.37858)$ & (1.75988) & (1.66188) \\
\hline \multirow[t]{2}{*}{10} & 94.62212 & 0.488173 & 0.177104 & 2.178423 & 1.344681 & 0.566681 \\
\hline & $(4.17655)$ & (2.30704) & $(1.81056)$ & $(2.38266)$ & (1.79203) & (1.42103) \\
\hline \multirow[t]{2}{*}{11} & 93.42910 & 0.56743 & 0.227613 & 0.219962 & 0.13881 & 0.10776 \\
\hline & (4.05534) & (2.25191) & (1.80433) & (2.37858) & (1.75988) & (1.66188) \\
\hline \multirow[t]{2}{*}{12} & 91.6799 & 0.67220 & 0.56145 & 0.45209 & 0.33156 & 0.227815 \\
\hline & (3.15191) & (2.70223) & (1.32568) & $(2.73488)$ & (3.72388) & $(2.45113)$ \\
\hline
\end{tabular}

Table 6. Variance Decomposition Results Of Stock Return Volatility.

When variance decomposition was analyzed in the 
subsequent phase, it shows from which variables share variance is formed, according to this, variance decomposition is shown in the following Table 6. Variance decomposition of common stock return series explained $45,42 \%$ by second default of REXC in Table 6 . Variance decomposition of stock exchange explained $23,55 \%$ by second default of RM1 in Table 6.

Table 7. F test of VAR Model - Stock Market Volatility and Macroeconomic Variables Volatility.

\begin{tabular}{lllllll}
\hline Time RANGE & RISE & RIP & RM1 & REXC & ROIL & RCPI \\
\hline $\begin{array}{l}\text { Power of estimate } \\
\text { stock market volatility (october } 2006-\text {-december }\end{array}$ & $1.423 * 18)$ & $1.705^{*}$ & $0.845^{*}$ & $0.529 *$ & 1.992 & 0.775 \\
\end{tabular}

*\%5 probability that statistically significant

Table 7 presents the results of the VAR model $F$ test between stock market volatility and each macroeconomic variable volatility. The stock market volatility powerty has relation only macroeconomic variables volatility money supply (M1) and industrial production index (IP), exchange rates $(\mathrm{EXC})$ volatility of the stock market and the volatility of each macroeconomic variable.

\section{Conclusion}

In this study the relationship between the stock market volatility and the main selected defining macroeconomic variables volatility are examined. The volatility of the variables are tried to find using

Asymmetric GARCH models. The best fit volatility is estimated with model selection criteria. The all variables havin fat tails structure so asymmetric distribution is more useful to find the reaal volatility.

According to VAR estimation, a significant relationship was found between the volatility of the stock market and the volatility of some macroeconomic variables. Results indicate the existence of an explanatory force from the volatility of stock market volatility to the stock is affected on the money supply volatility, exchange rate volatility and industrial production index volatility.

\section{Compliance with Ethical Standards}

1) All the authors do not have any possible conflicts of interest.

2) The authors declare that they have no competing interests.

Ethical approval: This article does not contain any studies with human participants or animals performed by any of the authors.

\section{References}

[1] Bollerslev, T., "A Conditional Heteroscedastic Time Series Model for Speculative Prices and Rates of Return", Review of Economicsand Statistics, 69, 1987, s. 5 42-547.
[2] Çağlayan, E., Dayıglu T. (2009). Döviz Kuru Getiri Volatilitesinin Koşullu Değişen Varyans Modelleri ile Öngörüsü, İstanbul Üniversitesi Iktisat Fakültesi Ekonometri ve İstatistik Dergisi, Ekonometri ve İstatistik Sayı. 9,1-6, s. 216.

[3] Davis, N., Kutan, A., "Inflation and Output as Predictors of StockReturns and Volatility: International Evidence", Applied Financial Economics, 13, 2003, s. 693-700. Clare, A. D.

[4] Ding, Z., Granger, C. W. J., \& Engle R. F. (1993). A Long Memory Property of Stock Market Returns and a New Model, Journal of Empirical Finance, 1, 83-106.

[5] Durukan B., "On the Relationship Between Stock Prices andMacroeconomic Variables in Istanbul Stock Exchange", ISEReview, 3, 1999, s. 11.

[6] Engle, R. F., G. G. J. Lee (1993), "A Permanent and Transitory Component Model of Stock Return Volatility", University of California, San Diego, Department of Economics, Discussion Paper, 9244.

[7] Glosten, L., Jagannathan, R., Runkle, D. (1993), Relationship between the expected value and volatility of the nominal excess returns on stocks. Journal of Finance, 48, 1779-1802.

[8] Groenewold, N., Fraser, P., "Share Price and Macroeconomic Factors", Journal of Business Finance and Accounting, 24, 1997, s. 1367-1383.

[9] Harris, R. D., C. C. Küçüközmen, "The Empirical Distribution of Stock Returns: Evidence From an Emerging European Market", Applied Economics Letters, 8, 2001, s. 367-371.

[10] Kwon, C. S., Shin, T. S., "Cointegration and Causality Between Macroeconomic Variables and Stock Market Returns", Global Finance Journal, 10 (1), 1999, s. 71-81.

[11] L1ljeblom, E., Stenius, M., "Macroeconomic Volatility and StockMarket Volatility: Empirical Evidence on Finnish Data", Applied Financial Economics, 7, 1997, s. 419-426.

[12] Mackinnon, J. G., "Critical Values for Cointegration Tests", in Engle, R. F. and Granger, C. W. J (eds), Long-run Economic Relationship, Oxford University Press, Oxford, 1991.

[13] Morelli, D., "The Relationship Between Conditional Stock Market Volatility and Conditional Macroeconomic Volatility Empirical Evidence Based on UK Data", International Review of Financial Analysis, 11, 2002, s. 101-110.

[14] Muradoğlu, F., “An Empirical Investigation of Stock Returns andDeterminants of Risk in an Emerging Market: GARCHMmodeling at ISE", Multinational Finance Journal, 3, 1999, s. 223252 .

[15] Nelson, D. B. (1991), Conditional heteroskedasticity in asset returns: a new approach. Econometrica, 59, 347-370.

[16] Payaslığlu, C., "Testing Volatility Asymmetry in Istanbul StockExchange" ISE Review, 5, 2001, s. 1-11. Schwert, G. W., "Why Does Stock Market Volatility Change OverTime?", Journal of Finance, 44, 1989, s. 1115-1153.

[17] Schwert, G. W., “Why Does Stock Market Volatility Change Over Time?”, Journal of Finance, 44, 1989, s. 1115-1153.

[18] Sims, C. A. (1980a), Macroeconomics and Reality, Econometrica 48, 1-48. 
[19] Tarı, R. (2006). Ekonometri. İstanbul: Avcı Ofset, 4. Bask1.

[20] Thomas, S. H., "Macroeconomic Factors, the APT and theUK Stock Market", Journal of Business Finance and Accounting, 21 (3), 1994, s. 309-330.

[21] Z. A., Aybar, B., "Volatility in Istanbul Stock Exchange", ISEReview, 2, 1998, s. 35-47.

[22] Yilmaz, M. K., "Stock Market Volatility and Its Term
Structure:Empirical Evidence From the Turkish Market", ISE Review, 1, 1997, s. 425-43.

[23] Zivot, E. (2000), Noteson Structural VAR Modeling, availableat:

http://www.eco.uc3m.es/ jgonzalo/teaching/timeseriesma/ziv otvarnotes reading.pdf

[24] www.tcmb.gov.tr TCMB Elektronik Veri Tabanı Dağıtım Sistemi. 